\title{
Multi-trait analysis of agroclimate variations during the growing season in east-central Poland (1971-2005)
}

\author{
Elżbieta Radzka ${ }^{1 *}$ and Katarzyna Rymuza ${ }^{2}$ \\ ${ }^{1}$ Department of Agrometeorology and Land Reclamation, ${ }^{2}$ Department of Quantitative Methods and Spatial Management, \\ University of Natural Sciences and Humanities, Prusa 14, 08-110 Siedlce, Poland
}

Received July 2, 2014; accepted February 16, 2015

\begin{abstract}
A b s t r a c t. The work is based on meteorological data recorded by nine stations of the Institute of Meteorology and Water Management located in east-central Poland from 1971 to 2005. The region encompasses the North Podlasian Lowland and the South Podlasian Lowland. Average values of selected agroclimate indicators for the growing season were determined. Moreover, principal component analysis was conducted to indicate elements that exerted the greatest influence on the agroclimate. Also, cluster analysis was carried out to select stations with similar agroclimate. Ward method was used for clustering and the Euclidean distance was applied. Principal component analysis revealed that the agroclimate of east-central Poland was predominantly affected by climatic water balance, number of days of active plant growth, length of the farming period, and the average air temperature during the growing season (Apr-Sept). Based on the analysis, the region of east-central Poland was divided into two groups (areas) with different agroclimatic conditions. The first area comprized the following stations: Szepietowo and Białowieża located in the North Podlasian Lowland and Biała Podlaska situated in the northern part of the South Podlasian Lowland. This area was characterized by shorter farming periods and a lower average air temperature during the growing season. The other group included the remaining stations located in the western part of both the Lowlands which was warmer and where greater water deficits were recorded.

$\mathrm{K}$ e y w o r d s: agroclimate, variation, growing season, principal component analysis, east-central Poland
\end{abstract}

\section{INTRODUCTION}

Agroclimate, soil, and natural topography are factors that determine what type of agricultural production is undertaken and how effective it is (Tosheva and Alexandrova, 2004; Shahbazi et al., 2009). Precipitation and thermal

*Corresponding author e-mail: elzbieta.radzka@uph.edu.pl conditions are basic meteorological factors affecting the conditions in which organisms live (Bochenek, 2012). From the point of view of agrometeorology, it is also important to describe atmospheric droughts as they often lead to water deficits, which hinder plant growth (Paltineanu et al., 2012). Changes in temperature and precipitation are likely to be different in individual regions. They will trigger further changes in the structure of water balance which may have a negative impact on agriculture (Usowicz et al., 2014; Zawadzki and Kędziora, 2014). Variation in air temperature is an important indicator of climatic risk associated with cultivation of many plant species (Żarski et al., 2010). What is more, there has recently been observed substantial variation in precipitation. As a result, a number of works have focused on the description of this meteorological component (Banaszkiewicz et al., 2004; Ścigalska and Łabuz, 2009). Variation in long-term thermal and pluviometric conditions should be examined based on selected indicators that characterize these conditions. In order to determine agroclimatic regions, it is necessary to demonstrate similarities or differences between values of long-term average components of agroclimate elements between individual stations located closest to one another. Polish agriculture is characterized by a marked regional variation in cultivated crops due to, among other things, natural conditions (Kuś and Krasowicz, 2001; Stuczyński et al., 2000; Ufnowska et al., 2001). Production effects in agriculture and an increase in the area of land under various crop plants, the cultivation of which has been either impossible or difficult so far, depend on the extent to which farmers adjust to the new climatic conditions.

(C) 2015 Institute of Agrophysics, Polish Academy of Sciences 
The issues pertaining to the assessment of agroclimate components in individual localities are multidimensional in character; therefore, to study these components, it is necessary to apply multi-trait methods because a comparative study examining them separately does not provide sufficient explanation of the complexity of these phenomena. A full assessment of agroclimate variation may be obtained by simultaneous application of multi-trait methods of variation as well as classification (grouping). To this end, principal component analysis (PCA) and cluster analysis are usually applied. Principal component analysis relies on obtaining uncorrelated linear functions of original characteristics (called principal components) so that the first, second, third trait etc. explains the greatest possible share of the multi-trait (total) variation (variance) of the objects studied. PCA makes it possible to detect the traits with the greatest share in the multi-trait variation between objects. Such traits are assumed to be the most important for the total variation (Thuiller, 2004; Lionello and Sanna, 2005; Pineda-Martinez et al., 2007). Cluster analysis is a group of multi-trait methods used to group objects taking into account many variables (traits) so as to allocate objects with similar values of these traits in the same groups called clusters (Królczyk and Tukiendorf, 2008).

In recent years, geostatistical methods have been widely applied in natural sciences to study spatial phenomena (Goovaerts, 1997; Miller, 2004; Zawadzki, 2002). The methods make it possible to better understand and precisely describe phenomena occurring in the environment. The aim of spatial analysis is to obtain information on the relationship between data and interactions between values of variables studied. Spatial relationship occurs when phenomena studied in a spatial unit contribute to an increase or decline in the probability of an occurrence of these phenomena in adjacent units (Zawadzki, 2011).

The objective of the study was to describe the spacial variation of agroclimate components during the growing season in east-central Poland.

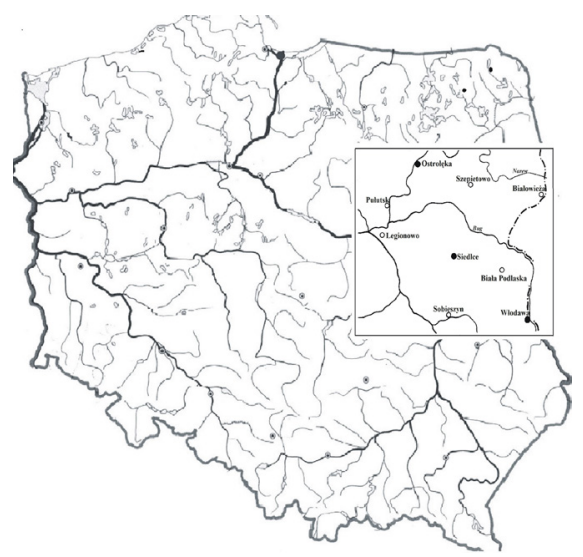

\section{MATERIALS AND METHODS}

The present work is based on meteorological data obtained from nine IMGW stations located in east-central Poland collected from 1971 to 2005 (Fig. 1, Table1).

The analysis included the following agroclimate components during the growing season from April to September:

- number of farming period, growing season, active plant growth;

- rainfall;

- precipitation sum;

- average air temperature;

- climatic water balance CWB;

- Sielianinov hydrothermal coefficient;

- and standardized precipitation index SPI.

Sielianinov hydrothermal coefficient is applied to assess thermal and pluviometric conditions:

$$
K=\frac{P 10}{\Sigma t},
$$

where: $P$ - monthly atmospheric precipitation sum $(\mathrm{mm})$, $\Sigma t$ - sum of average daily air temperatures $>0^{\circ} \mathrm{C}$.

Values of the standardized precipitation index (SPI) were based on the following equation:

$$
S P I=\frac{f(P)-\mu}{\sigma},
$$

where: $S P I$ - standardized precipitation index, $f(P)=\sqrt[3]{P}$ - converted precipitation sum, $\mu$ - average value of normalized precipitation sequence, $\sigma$ - average standard deviation of normalized precipitation sequence.

There were three steps in the statistical analysis of the variation in agroclimatic conditions in east-central Poland. First, average values of the indicators studied in the growing season were determined. As the values had different units, the variables were standardized prior to the multidimensional analyses. Next, principal component analysis (PCA) was conducted: the number of variables included in the analysis was determined based on the Kaiser criterion

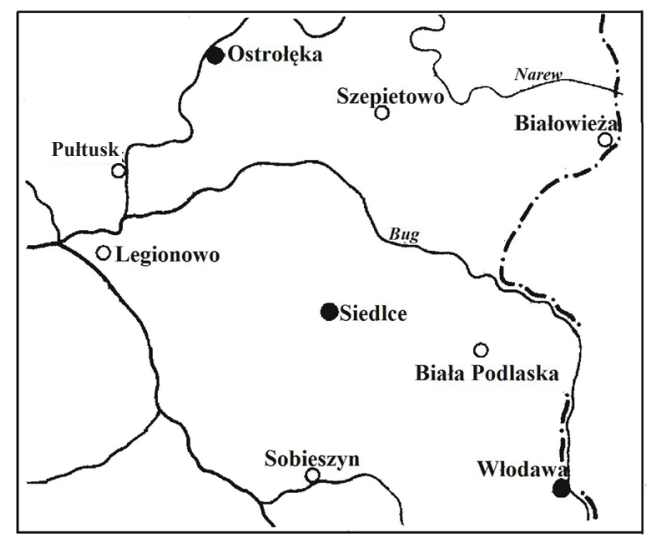

Fig. 1. Stations in east-central Poland. 
T a b l e 1. Geographic coordinates of synoptic and climatic stations in central-eastern Poland

\begin{tabular}{|c|c|c|c|}
\hline \multirow{2}{*}{ Station } & \multicolumn{2}{|c|}{ Geographic coordinates } & \multirow{2}{*}{$\begin{array}{c}\mathrm{H}_{\mathrm{s}} \\
\text { (m a.s.1.) }\end{array}$} \\
\hline & $\varphi^{\circ}$ & $\lambda^{\circ}$ & \\
\hline Ostrołęka & $53^{\circ} 05^{\prime}$ & $21^{\circ} 34^{\prime}$ & 95 \\
\hline Białowieża & $52^{\circ} 42^{\prime}$ & $23^{\circ} 51^{\prime}$ & 164 \\
\hline Włodawa & $51^{\circ} 33^{\prime}$ & $23^{\circ} 32^{\prime}$ & 163 \\
\hline Szepietowo & $52^{\circ} 51^{\prime}$ & $22^{\circ} 33^{\prime}$ & 150 \\
\hline Legionowo & $52^{\circ} 24^{\prime}$ & $20^{\circ} 58^{\prime}$ & 93 \\
\hline Biała Podlaska & $52^{\circ} 02^{\prime}$ & $23^{\circ} 05^{\prime}$ & 133 \\
\hline Sobieszyn & $51^{\circ} 37^{\prime}$ & $22^{\circ} 09^{\prime}$ & 135 \\
\hline Pułtusk & $52^{\circ} 44^{\prime}$ & $21^{\circ} 06^{\prime}$ & 95 \\
\hline Siedlce & $52^{\circ} 11^{\prime}$ & $22^{\circ} 16^{\prime}$ & 146 \\
\hline
\end{tabular}

$\varphi^{\circ}$ - geographic latitude, $\lambda^{\circ}$ - geographic longitude, $\mathrm{H}_{\mathrm{s}}$ - elevation above sea level.

T a b l e 2. Eigenvalues, variance percentages, and cumulative variance percentages of the principal components analysis

\begin{tabular}{cccc}
\hline Principal component & Eigenvalues & $\begin{array}{c}\text { Explained part of multivariate } \\
\text { variation of accessions }\end{array}$ & $\begin{array}{c}\text { Cumulative part of } \\
\text { multivariate variation }\end{array}$ \\
\hline PC 1 & 3.99 & 44.41 & 44.41 \\
PC 2 & 1.79 & 19.94 & 64.36 \\
PC 3 & 1.43 & 15.89 & 80.25 \\
PC 4 & 0.99 & 11.10 & 91.35 \\
PC 5 & 0.34 & 3.77 & 95.12 \\
PC 6 & 0.24 & 2.63 & 97.75 \\
PC 7 & 0.17 & 1.91 & 99.66 \\
PC 8 & 0.03 & 0.34 & 100.00 \\
\hline
\end{tabular}

according to which only factors with eigenvalues greater than 1 are retained for further analysis (Stanisz, 2007). Finally, cluster analysis was conducted, which made it possible to classify the stations in terms of agroclimate components. Grouping was obtained by Ward's method and the Euclidean distance was applied. The agglomeration course and Mojena rule were used to determine the dendrogram intersection point (Kasina, 2008; Królczyk and Tukiendorf, 2008; Stanisz, 2007). In order to check if the classification obtained using the agglomeration method was correct, the objects were classified again (k-means clustering) into the number of groups which was obtained by the agglomeration method (Holden and Brereton, 2004), the results of grouping being the same for both the methods.

\section{RESULTS}

The principal component analysis (PCA) showed that the agroclimate of east-central Poland was differentiated by indicators associated with the first three components: PC1, PC2, and PC3 (as their eigenvalues were greater than 1). The first, second, and third component explained, respectively, over $40,19.94$, and $15.89 \%$ of the agroclimate variation (Table 2). Parameters associated with the first principal component, that is climatic water balance (CWB), average number of days of active plant growth, number of days of the farming period, and average air temperature during the growing season had the greatest effect on the agroclimate of the localities in the North Podlasian Lowland and the South Podlasian Lowland. 
T a b l e 3. Factorial loadings of the principal components (PC 1, PC 2, PC 3) and diagnostic traits, eigenvalues, and cumulative eigenvalues of the components

\begin{tabular}{llll}
\hline Trait & PC 1 & PC 2 & PC 3 \\
\hline Number of days of the growing season & -0.577 & 0.214 & -266 \\
Number of days of the farming period & -0.818 & -0.310 & 0.087 \\
Number of days of active plant growth & -0.839 & -0.751 & 0.053 \\
$\begin{array}{l}\text { Precipitation sum during the growing season } \\
\text { Apr-Sept) }\end{array}$ & 0.118 & 0.225 & 0.544 \\
$\begin{array}{l}\text { Average air temperature during the growing season } \\
\text { (Apr-Sept) }\end{array}$ & -0.805 & 0.901 \\
Number of days with rainfall (Apr-Sept) & & 0.063 \\
Climatic water balance CWB (Apr-Sept) & 0.263 & 0.127 \\
Sielianinov hydrothermal coefficient (Apr-Sept) & 0.884 & -0.254 \\
Standardized precipitation index SPI (Apr-Sept) & -0.450 & 0.042 & -0.703 \\
\hline
\end{tabular}

The first principal component was positively correlated with climatic water balance (CWB) (0.884) and negatively correlated with the average number of days of active plant growth (-0.839), number of days of the farming period $(-0.818)$, and the average air temperature during the growing season (Apr-Sept) (-0.805) (Table 3). The relationships indicate that localities with a higher index of climatic water balance have also got a lower average number of days of active plant growth, a lower average number of days of farming period, and a lower average air temperature. The number of days when precipitation was recorded and the precipitation sum during the growing season (Apr-Sept) were the most strongly associated with the second principal component, which explained around $20 \%$ of the variation. The values of the correlation coefficient indicate that the average number of days with precipitation was lower in localities with a higher precipitation sum. The third principal component was associated with Sielianinov hydrothermal coefficient (-0.703). The relationships between PC3 and the remaining indicators demonstrate that in stations where greater water deficits were observed the relatively many days of thermal periods were accompanied by high air temperatures during the growing season (Fig. 2).

The cluster analysis yielded 2 groups of stations with different agrometeorological conditions in east-central Poland (Fig. 3). Group 1 consisted of two stations (Szepietowo and Białowieża) located in the North Podlasian Lowland and Biała Podlaska situated in the east of the South Podlasian Lowland. The second group was made up of the remaining stations (Pułtusk, Sobieszyn, Legionowo, Siedlce, Włodawa, and Ostrołęka) located in the western part of the study area. The agroclimate of the North Podlasian Lowland had relatively shorter thermal periods and lower

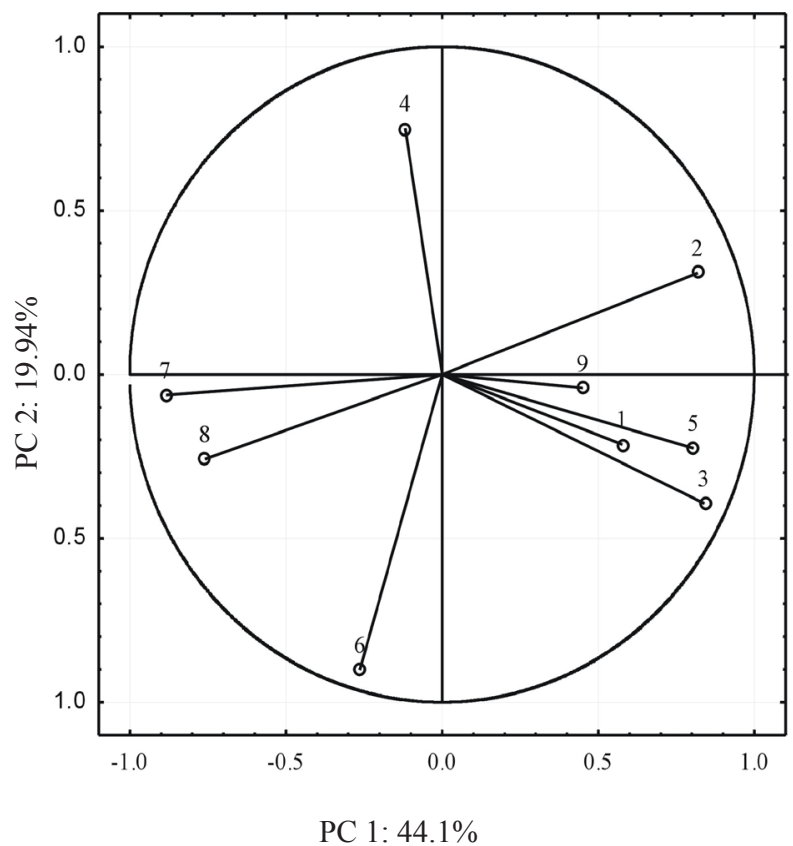

Fig. 2. Location of agroclimate components in the space of the PC 1 and PC 2 components. Number of days of: 1 - growing season, 2 - farming period, 3 - active plant growth; 4 - precipitation sum during the growing season (Apr-Sept), 5 - average air temperature during the growing season (Apr-Sept), 6 - number of days with rainfall (Apr-Sept), 7 - climatic water balance CWB (Apr-Sept), 8 - Sielianinov hydrothermal coefficient (Apr-Sept), 9 - standardized precipitation index SPI (Apr-Sept). 


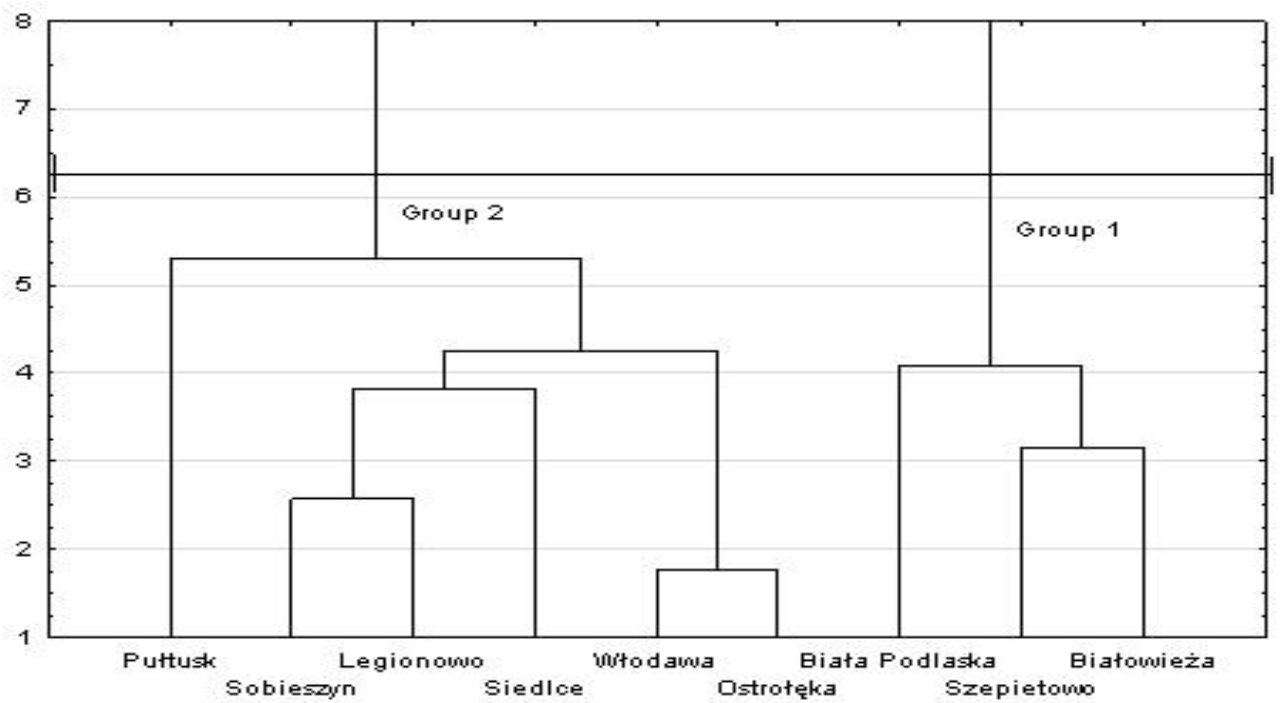

Fig. 3. Dendrogram demonstrating groups of stations formed using cluster analysis.

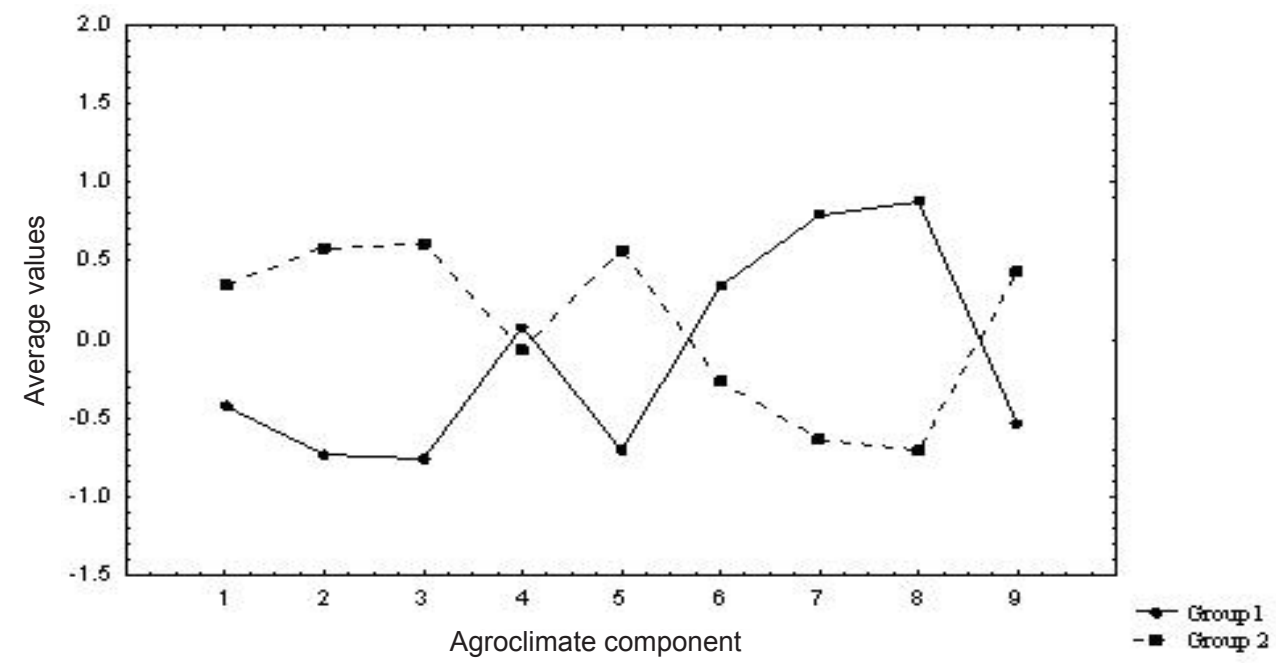

Fig. 4. Average values of agroclimate components of the obtained clusters. Group 1: Biała Podlaska, Szepietowo, Białowieża; Group 2: Pułtusk, Sobieszyn, Legionowo, Siedlce, Włodawa, Ostrołęka. Other explanations as in Fig. 2.

average air temperature during the growing season, compared with group 2 (Fig. 4). The values of the standardized precipitation index (SPI) for the group 1 stations were lower compared with group 2. However, group 2 area had lower values of climatic water balance (CWB) and Sielianinov's coefficient, which indicates that water deficit was greater in this area. Sums of atmospheric precipitation during the growing season in the North Podlasian Lowland (group 1) were slightly higher compared with the remainder of the study area.

\section{DISCUSSION}

Climate change, at a global, regional, local, and point scale, has recently become a significant issue (Kundzewicz, 2011; Starkel and Kundzewicz, 2008). The necessity to assess agroclimate variation for smaller and smaller areas results from the fact that it is very variable spatially.

Similarly to Gong and Richman (1995) as well as Widmann and Schär (1997), the variation of east-central Poland agroclimate was studied simultaneously in terms of many elements by means of principal component 
analysis and cluster analysis. The PCA revealed that, in 1971-2005, indicators associated with the first three principal components PC1, PC2, and PC 3 in $80.25 \%$ accounted for agroclimate variation. The first principal component explained $20 \%$ of the variation and was most strongly correlated with climatic water balance. According to Legates and McCabe (2005), climatic water balance is one of the major measures of assessing region moisture conditions. It was also demonstrated in the work that the first principal component was correlated with the average number of days of thermal periods as well as average air temperature during the growing season (Apr-Sept). Żmudzka and Dobrowolska (2001) have reported that variation in the length of the growing season is by more than 10 to $61 \%$ determined by NAO (North Atlantic Oscillation) variation. The effect of NAO on the beginning and length of the growing season declines in the direction from the northwest and west of Poland to the south-east.

The analysis of agroclimate variation also demonstrated that the number of days with recorded precipitation and precipitation sum over the growing season (Apr-Sept) were most strongly associated with the second component, which explained around $20 \%$ variation.

Variation in precipitation is to a great extent affected by atmospheric circulation, which determines which impacts, continental or oceanic, are more pronounced, thus determining the climate at a global and local scale (Twardosz et al., 2011). Continental properties of the climate are more pronounced in the east of Poland, extending from Suwałki to Nowy Sącz, but they are also present over most of Poland area. The dominance of these properties in north-eastern Poland is most visible in the yearly precipitation pattern as summer rainfall is higher than winter precipitation (summer rainfall sum is twice as high as winter precipitation sum) (Górniak, 2000).

Two groups of stations (areas) with different agrometeorological conditions were formed in east-central Poland. Group 1 consisted of two stations (Szepietowo and Białowieża) located in the North Podlasian Lowland and Biała Podlaska situated in the eastern part of the South Podlasian Lowland. This area was characterized by shorter thermal periods and a lower average air temperature during the growing season. Group 2 included the remaining, that is western, part of the study area. Compared with group 2, the agroclimate of the North Podlasian Lowland had shorter thermal periods and a lower average air temperature for the growing season. Ziernicka-Wojtaszek (2009) have stated that the Podlasian Lowland is part of a moderately cold and optimally wet region. By contrast, the central lowland part of Poland, including the Mazovia Lowland, is moderately warm and moderately dry. According to Ziernicka-Wojtaszek and Zawora (2008), the Białostocka Upland (which is part of the South Podlasian Lowland) was moderately cold and moderately dry.
The methods applied in the present work may be used to assess agroclimate variation in other parts of Poland and the meteorological data for analysis can be obtained online at www.ogimet.com (Przeździecki et al., 2014).

\section{CONCLUSIONS}

1. The agroclimate of east-central Poland was predominantly affected by climatic water balance, number of days of active plant growth, farming period and average air temperature during the growing season (April-September).

2. Two regions were distinguished in the east-central part of Poland based on the variation of agroclimate components. The first region includes the north-east and east-central part where thermal periods are shorter and average air temperatures are lower during the growing season. The remaining area, which was designated as the second region, is a part of the study area characterized by a greater water deficit and higher average air temperatures.

3 . The agroclimate of the study area, which was relatively small, was rather uniform. However, the division into regions may be used while conducting evaluation of agricultural production area in east-central Poland.

\section{REFERENCES}

Banaszkiewicz B., Grabowska K., and Szwejkowski Z., 2004. Description of precipitation in Warmia-Masuria Province in 2000-2002. Acta Agrophysica, 3(1), 5-11.

Bochenek W., 2012. Evaluation of precipitation at the IG and SO PAS research station in Szymbark during 40-year period (1971-2010) and its impact on the variability of runoff from the Bystrzanka stream basin. Woda-Środowisko-Obszary Wiejskie, 12, 2(38), 29-44.

Gong X. and Richman M.B., 1995. On the application of cluster analysis to growing season precipitation data in North America East Rockies J. Climate, 8(4), 897-931.

Goovaerts P., 1997. Geostatistics for natural resources evaluation. Oxford University Press, New York, USA.

Górniak A., 2000. Climate of Podlasie Province. IMGW Białystok Branch, Białystok, Poland.

Holden N.M. and Brereton A.J., 2004. Definition of agroclimatic regions in Ireland using hydrothermal and crop yield data. Agric. Forest Meteorol., 122, 175-191.

Kasina M., 2008. Variation of snow cover chemistry between Kraków and the Upper Silesian Industrial Area. Prace Geograficzne UJ, Kraków, 120, 51-64.

Królczyk J. and Tukiendorf M., 2008. Research on the impact of mass fractions of multi-element granular structure on the mixing process. Int. Agrophys., 22, 45-52.

Kundzewicz Z.W., 2011. Changes in the climate - their causes and consequences - observations and projections. Landform Analysis, 15, 39-49.

Kuś J. and Krasowicz S., 2001. Natural and organisational conditions of sustainable development of agricultural holdings. Pamiętniki Puławskie, 124, 273-295.

Legates D.R. and McCabe G.J., 2005. A re-evaluation of the average annual global water balance. Physical Geography, 26, 467-479. 
Lionello P. and Sanna A., 2005. Mediterranean wave climate variability and its links with NAO and Indian Monsoon. Climate Dynamics, 25, 611-623.

Miller H.J., 2004. Tobler's First Law and Spatial Analysis. Annals Assoc. American Geographers, 94,(2), 284-289.

Paltineanu C., Chitu E., and Mateescu E., 2012. New trends for reference evapotranspiration and climatic water deficit. Int. Agrophys., 26, 159-165.

Pineda-Martínez L.F., Carbajal N., and Medina-Roldán E., 2007. Regionalization and classification of bioclimatic zones in the central-northeastern region of Mexico using principal component analysis (PCA). Atmósfera, 20(2), 133-145.

Przeździecki K., Zawadzki J., and Sikorski W., 2014. Obtaining free data at www.ogimet.com - an online weather service. Roczniki Geomatyki, XII, 3(65), 317-326.

Shahbazi F., Jafarzadeh A., Sarmadian F., Neyshaboury M.R., Oustan S., Anaya-Romero M., Lojo M., and de la Rosa D., 2009. Climate change impact on land capability using MicroLEIS DSS, Int. Agrophys., 23, 277-286.

Stanisz A., 2007. An easy course in statistics using STATISTICA PL software and medical examples. Multidimensional Analyses. Stat Soft Kraków, Poland.

Starkel L. and Kundzewicz Z.W., 2008. Consequences of changes in the climate on the spatial management of the country. Nauka, 1, 85-101.

Stuczyński T., Budzyńska K., Gawrysiak L., and Zalewski A., 2000. Evaluation of agricultural production area in Poland. Biul. Inf. IUNG, 12, 4-17.

Ścigalska B. and Labuz B., 2009. Analysis of variation of pluviometric conditions from April to July in the Kraków area (1961-1990). Acta Agrophysica, 13(2), 505-521.

Thuiller W., 2004. Patterns and uncertainties of species' range shifts under climate change. Global Change Biology, 10, 2020-2027.

Tosheva E. and Alexandrova P., 2004. Influence of some meteorological factors on fertilizer use efficiency in winter wheat growing. Int. Agrophysics, 18, 285-288.
Twardosz R., Niedźwiedź T., and Lupikasza E., 2011. The influence of atmospheric circulation on the type of precipitation (Kraków, southern Poland). Theoretical and Applied Climatology, 104, 233-250.

Ufnowska J., Kopiński J., and Madej A., 2001. Regional diversification of animal production in Poland. Pamiętniki Puławskie, 124, 395-402.

Usowicz B., Marczewski W., Usowicz J. B., Lukowski M. and Lipiec J., 2014. Comparison of surface soil moisture from SMOS satellite and ground measurements. Int. Agrophys., 28, 359-369.

Widmann M. and Schär C.A., 1997. Principal component and longterm trend analysis of daily precipitation in Switzerland. Int. J. Climatology, 17(12), 1333-1356.

Zawadzki J., 2002. Utilisation of geostatistical data for spatial data analysis. Wiadomości Statystyczne Głównego Urzędu Statystycznego, 12, 23-37.

Zawadzki J., 2011. Geostatistical methods for natural sciences and technical fields of study. Oficyna Wydawnicza Politechniki Warszawskiej, Poland.

Zawadzki J. and Kędzior M., 2014. Statistical analysis of soil moisture content changes in Central Europe using GLDAS database over three past decades. Central Eur. J. Geosci., 6, 344-353.

Ziernicka-Wojtaszek A., 2009. Verification of agricultural and climatic regionalization of Poland in the light of modern changes in the climate. Acta Agrophysica, 13(3), 803-812.

Ziernicka-Wojtaszek A. and Zawora T., 2008. Pluviometric diversification of Poland in the light of present-day climate change. Acta Agrophysica, 12(1), 289-297.

Żarski J., Dudek S., and Kuśmierek-Tomaszewska R., 2010. Tendencies in air temperature change in the area of Bydgoszcz. Infrastruktura i Ekologia Terenów Wiejskich, 2, 131-141.

Żmudzka E. and Dobrowolska M., 2001. Thermal growing season in Poland - spatial variation and time variability. Scientific Reviev Engineering and Environmental Sciences, 21, 75-80. 